\title{
PENYUSUNAN LAPORAN KEUANGAN UMKM BERBASIS SAK EMKM
}

\author{
Dabella Yunia ${ }^{1 *}$, Galih Fajar Muttaqin ${ }^{1}$, Windu Mulyasari', Kurniasih Dwi Astuti ${ }^{1}$, Nana Nofianti ${ }^{1}$, Tri \\ Wahyudi ${ }^{1}$,Muhammad Nawawi ${ }^{1}$,Chandra Prasadhita ${ }^{1}$ \\ ${ }^{1}$ Diploma III Akuntansi, Universitas Sultan Ageng Tirtayasa \\ *Coresponding-Author : dabellayunia@untirta.ac.id
}

\begin{abstract}
ABSTRAK. Pelaku usaha mikro, kecil dan menengah memiliki permasalahan pencatatan keuangan. Tujuan artikel ini dibuat adalah memberikan pemahaman tentang pentingnya menyusun laporan keuangan bagi usaha mikro, kecil dan menengah dan memberikan pemahaman tentang Standar Akuntansi Keuangan Entitas Mikro, Kecil, dan Menengah. Kegiatan yang dilakukan untuk memberikan pemahaman melalui kegiatan workshop penyusunan laporan keuangan usaha mikro, kecil, dan menengah berbasis standar akuntansi entitas mikro, kecil dan menengah. Kegiatan tersebut dilakukan melalui tiga tahap, yaitu pendahuluan, workshop, dan pendampingan. Pada tahap pendahuluan dilakukan pendataan peserta kegiatan workshop. Tahap workshop merupakan kegiatan workshop yang terdiri atas ceramah, praktik dan tanya jawab. Ceramah dilakukan penyampaian materi di kelas, praktik dilakukan dengan menggunakan aplikasi. Tahap selanjutnya adalah pendampingan yang dilaksanakan secara online. Setelah kegiatan tersebut dilakukan, pelaku usaha memahami pentingnya laporan keuangan dan mampu menyusun laporan keuangan minimal sesuai dengan standar akuntansi keuangan bagi entitas mikro, kecil dan menengah berupa laporan posisi keuangan, laporan laba rugi dan catatan atas laporan keuangan.
\end{abstract}

Kata Kunci: Laporan Keuangan, Standar Akuntansi Keuangan Entitas Mikro, Kecil, dan Menengah, Usaha Mikro Kecil Menengah

\begin{abstract}
Micro, small and medium enterprises have problems with financial records. The purpose of this article is to provide an understanding of the importance of preparing financial reports for micro, small and medium enterprises and to provide an understanding of the Financial Accounting Standards for Micro, Small and Medium Entities. Activities carried out to provide understanding through workshops on the preparation of financial reports for micro, small and medium enterprises based on accounting standards for micro, small and medium entities. The activity was carried out in three stages, namely introduction, workshop, and mentoring. At the preliminary stage, the participants of the workshop were collected data. The workshop stage is a workshop activity consisting of lectures, practice and questions and answers. Lectures are delivered in class, practice is carried out using applications. The next stage is mentoring which is carried out online. After these activities are carried out, business actors understand the importance of financial statements and are able to prepare financial statements at least in accordance with financial accounting standards for micro, small and medium entities in the form of statements of financial position, income statements and notes to financial statements.
\end{abstract}

Keyword: financial reports, Financial Accounting Standards for Micro Small and Medium Entities, Micro Small and Medium Enterprises

\section{PENDAHULUAN}

UMKM merupakan singkatan dari Usaha Mikro, Kecil dan Menengah. Berdasarkan singkatan tersebut, maka tergambar bahwa usaha berskala kecil. Walaupun terkesan kecil namun dampak UMKM besar bagi negara berkembang, termasuk Indonesia. Secara umum, terdapat tiga peran UMKM atau kontribusi UMKM terhadap perekonomian Indonesia meliputi: (1) Sarana Pemerataan 
Tingkat Ekonomi Rakyat Kecil. UMKM berperan dalam pemerataan tingkat perekonomian rakyat sebab berada di berbagai tempat. UMKM bahkan menjangkau daerah yang pelosok sehingga masyarakat tidak perlu ke kota untuk memperoleh penghidupan yang layak. (2) Sarana Mengentaskan Kemiskinan. UMKM berperan untuk mengentaskan masyarakat dari kemiskinan sebab angka penyerapan tenaga kerja terhitung tinggi. (3) Sarana Pemasukan Devisa bagi Negara. Sejatinya UMKM sumbang devisa bagi negara sebab pasarnya tidak hanya menjangkau nasional melainkan hingga ke luar negeri.

Tabel 1. Jumlah Usaha Mikro, Kecil dan Menengah menurut Kabupaten/Kota di Provinsi Banten Tahun 2018

\begin{tabular}{llrrrr}
\hline No & \multicolumn{1}{c}{ Kabupaten/Kota } & Usaha Mikro & Usaha Kecil & $\begin{array}{c}\text { Usaha } \\
\text { Menengah }\end{array}$ & Jumlah UKM \\
\hline 1 & Kabupaten Lebak & 49.498 & 825 & 15 & 50.338 \\
2 & Kabupaten Tangerang & 41.155 & 0 & 0 & 41.155 \\
3 & Kabupaten Serang & 22.667 & 3.958 & 284 & 26.909 \\
4 & Kota Tangerang & 11.079 & 633 & 34 & 11.746 \\
5 & Kota Cilegon & 6.446 & 100 & 0 & 6.546 \\
6 & Kota Serang & 6.495 & 3.595 & 222 & 10.321 \\
7 & Kota Tangerang Selatan & 7.094 & 2.488 & 0 & 9.582 \\
8 & Kabupaten Pandeglang & 900 & 100 & 2 & 1.002 \\
\hline
\end{tabular}

Sumber: Dinas Koperasi dan UKM Provinsi Banten

Peran UMKM dirasakan bukan hanya pada tingkat negara, namun juga pada tingkat daerah. Berdasarkan data tahun 2018 dari Dinas Koperasi dan UKM, jumlah usaha mikro, kecil, dan menengah di Provinsi Banten berjumlah 157.599. Secara statistik ini jumlah yang cukup besar. Hal ini menunjukkan potensi besar untuk menopang perekonomian di Provinsi Banten. Berikut ini data sebaran UMKM setiap Kabupaten/Kota di Provinsi Banten. Jumlah UMKM yang banyak ternyata tidak diimbangi dengan pengelolaan usaha yang profesional. Data SE2016 menunjukkan bahwa pengelolaan UMKM dilakukan secara sederhana, tidak ada sistem pencatatan yang menghasilkan laporan keuangan. Pelaku UMKM belum memahami perbedaan antara pendapatan dan laba usaha, sehingga dalam menjalankan usaha pelaku UMKM menganggap bahwa pendapatan yang diterima pada saat transaksi itu adalah laba. Sehingga pelaku UMKM menggunakan pendapatan atau omset mereka untuk memenuhi kebutuhan rumah tangga, bukan untuk mengembangkan usaha.

UMKM dapat maju dan berkembang bila didukung dengan administrasi yang baik. Salah satu administrasi yang harus ada pada UMKM adalah laporan keuangan. Laporan keuangan bagi UMKM memiliki manfaat sebagai bahan analisis tentang perkembangan usaha UMKM, bentuk pertanggungjawaban kepada pemodal dan kreditur, sebagai bahan pertimbangan untuk Langkah usaha yang selanjutnya (Febriyantodkk, 2019). Pentingnya laporan keuangan bagi UMKM juga mendorong asosiasi akuntan, yaitu Ikatan Akuntan Indonesia menerbitkan Standar Akuntansi Keuangan Entitas Mikro Kecil dan Menengah (SAK EMKM). Pelaku UMKM dapat menyusun laporan keuangan berdasarkan SAK EMKM.

SAK EMKM merupakan sebuah standar penyusunan laporan keuangan yang digunakan oleh EMKM untuk menyusun laporan keuangan. Laporan keuangan merupakan laporan yang bertujuan untuk menyediakan informasi posisi keuangan dan kinerja suatu entitas yang bermanfaat bagi sejumlah besar pengguna dalam pengambil keputusan ekonomi oleh siapa pun yang tidak posisi dapat meminta laporan keuangan khusus untuk memenuhi kebutuhan informasi tersebut. Laporan keuangan berdasarkan SAK EMKM minimal menyajikan laporan keuangan berupa: Laporan posisi keuangan pada akhir periode; Laporan laba rugi selama periode; dan Catatan atas laporan keuangan, yang berisi tambahan dan rincian pos-pos tertentu yang relevan. Artikel ini disusun untuk 
memberikan pemahaman tentang pentingnya menyusun laporan keuangan UMKM dan memberikan pemahaman tentang SAK EMKM.

\section{ANALISIS PERMASALAHAN}

Hasil identifikasi yang diperoleh terhadap mitra UMKM yang ada di Provinsi Banten. mitra UMKM tersebut berdomisili di Kota Serang. UMKM tersebut sudah berjalan lebih dari satu tahun. Produk andalan UMKM tersebut memiliki keunikan, maka tidak takut bersaing dengan jenis usaha yang sama. Permasalahan dari mitra adalah belum menyusun laporan keuangan dan kurangnya pemahaman tentang pendapatan dan laba, sehingga tidak dapat menghasilkan laporan keuangan yang relevan dan reliable. Hal ini berdampak bahwa UMKM tidak dapat menganalisis perkembangan usahanya.

\section{SOLUSI YANG DITAWARKAN}

Berdasarkan hasil identifikasi masalah, dimana ditemukan beberapa masalah yang dihadapi oleh pelaku UMKM di Banten adalah UMKM belum menyusun laporan keuangan dan kurangnya pemahaman tentang pendapatan dan laba. Solusi yang diberikan oleh tim pengabdian kepada masyarakat untuk pelaku UMKM di Banten yaitu:

Tahap 1. Pendahuluan. Tim pengabdian kepada masyarakat menentukan masalah yang paling krusial untuk diselesaikan dengan segera. Dari dua masalah yang berhasil diidentifikasi, yaitu UMKM belum menyusun laporan keuangan dan kurangnya pemahaman tentang pendapatan dan laba, maka tim pengabdian kepada masyarakat memutuskan untuk menyelenggarakan kegiatan tentang laporan keuangan bagi UMKM. Pada tahap pertama, tim bekerja sama dengan pihak lain, yaitu Rumah Kreatif BUMN Serang, dimana pada Ruma Kreatif BUMN Serang memberikan tempat bagi UMKM untuk mengembangkan ketrampilan. Kerja sama ini dilakukan untuk menjaring peserta, yaitu pelaku UMKM yang membutuhkan pengetahuan tentang laporan keuangan UMKM. Tim pengabdian masyarakat membuka pendaftaran untuk kegiatan Workshop Penyusunan Laporan Keuangan UMKM berbasis SAK EMKM, kemudian peserta yang telah mendaftar dan dipastikan dapat hadir akan dikumpulkan pada satu grup media sosial (What's App) untuk memudahkan koordinasi.

Tahap 2. Workshop. Tim pengabdian kepada masyarakat melaksanakan kegiatan dengan tema "Workshop Penyusunan Laporan Keuangan UMKM berbasis SAK EMKM". Workshop ini dihadiri oleh pelaku UMKM di Provinsi Banten yang bergabung dalam Rumah Kreatif BUMN Serang. Kegiatan dilaksana pada hari Senin, 21 Juni 2021 bertempat di Rumah Kreatif BUMN Serang. Kegiatan ini dilaksanakan berdasarkan metode ceramah, praktik dan tanya jawab. Pada kegiatan workshop tersebut memberikan pengetahuan dan ketrampilan UMKM untuk menyusun laporan keuangan. Pada kegiatan Workshop Penyusunan Laporan Keuangan UMKM berbasis SAK EMKM, pelaku UMKM diberikan materi tentang manfaat laporan keuangan, alasan menyusun laporan keuangan UMKM harus berdasarkan SAK EMKM, dan juga bagaimana menyusun laporan keuangan bagi UMKM. Pada materi penyusunan laporan keuangan, pemateri menjelaskan perbedaan antara pendapatan dan laba menurut bahasa yang mudah dipahami oleh pelaku UMKM. Setelah diadakan ceramah, pemateri memberikan solusi bagi peserta workshop bagaimana menyusun laporan keuangan yang praktis, yaitu melalui Smartphone yaitu dengan menggunakan aplikasi Akuntansi UKM. Aplikasi tersebut dapat didownload secara gratis. Peserta diperkenankan untuk melakukan download aplikasi terlebih dahulu, kemudian akan dilakukan praktik bersamasama. Pemateri memberikan praktik menyusun laporan keuangan menggunakan smartphone karena seluruh peserta menggunakan smartphone, selain itu pada kehidupan sehari-hari pasti pelaku UMKM tidak lepas dari smartphone. Pemateri memberikan kasus secara singkat tentang usaha "Brownis" sebagai praktik, supaya peserta UMKM terbiasa dengan aplikasi Akuntansi UKM tersebut. Kasus yang diberikan berupa transaksi harian pada usaha "Brownis", transaksi tersebut 
diinput satu per satu sesuai tanggal transaksi, setelah semua transaksi semua diinput dengan benar, peserta dapat melihat hasilnya berupa laporan keuangan, yang terdiri atas neraca saldo, laporan laba rugi, dan neraca. Tim pengabdian kepada masyarakat juga memberikan materi dan modul kepada peserta secara gratis dalam bentuk softfile yang dibagikan melalui grup pada media sosial. Pada akhir acara, peserta diberikan evaluasi berupa kuis melalui aplikasi Khoot.it, dimana peserta dengan 3 nilai tertinggi mendapatkan hadiah. Hal ini dilakukan sebagai bentuk apresiasi penyelenggara pada peserta.

Tahap ketiga adalah pendampingan. Tim pengabdian kepada masyarakat melakukan pendampingan kepada peserta workshop. Peserta worshop diberikan kesempatan melakukan input transaksi keuangan pada Aplikasi UKM. Jika peserta UKM mengalami kesulitan atau lupa dapat membuka modul yang dibagikan atau bertanya pada tim pengabdian kepada masyarakat pada grup media sosial yang telah terbentuk. Kegiatan pendampingan ini memang lebih banyak dilakukan melalui grup media sosial karena masih pada keadaan pandemi Covid-19. Pada periode pendampingan, peserta menyerahkan laporan keuangan usaha masing-masing pada tim pengabdian kepada masyarakat untuk dapat dievaluasi sejauh mana telah diterapkan.

\section{HASIL DAN PEMBAHASAN}

UMKM yang menjadi peserta Workshop Penyusunan Laporan Keuangan UMKM berbasis SAK EMKM terdiri atas UMKM berdomisili di Provinsi Banten. Tujuan dari kegiatan ini memberikan pemahaman tentang pentingnya menyusun laporan keuangan UMKM dan memberikan pemahaman tentang SAK EMKM. Peserta yang hadir pada kegiatan ini telah melakukan pencatatan sederhana atas usahanya, yaitu catatan keluar dan masuk. Pencatatan yang baik dan benar seharusnya digolongkan pada masing-masing akun, yaitu aset, liabilitas, ekuitas, pendapatan dan beban. Peserta kegiatan workshop ini diberikan materi tentang penggolongan akun-akun tersebut, mana yang termasuk pada kategori aset, liabilitas, ekuitas, pendapatan dan beban. Hal yang menjadi tantangan pada saat melakukan kegiatan pengabdian kepada masyarakat adalah cara penyampaian pemateri kepada peserta. Materi yang disampaikan kepada peserta disajikan sederhana tanpa mengurangi substansi. Setelah penyampaian terkait akun, pemateri juga menyampaikan bagaimana mencatat transaksi berupa jurnal akuntansi.

Pada saat kegiatan berlangsung, materi tentang jurnal disampaikan dengan mencontohkan transaksi yang berkaitan dengan usaha yang dijalankan UMKM yang hadir saat itu. Pemberian contoh secara langsung bertujuan memberikan pemahaman pada UMKM untuk mencatat transaksi pada Aplikasi UKM. Menyusun laporan keuangan bagi UMKM merupakan hal harus mendapatkan perhatian bagi UMKM. Pelaku UMKM dapat mengetahui kondisi usaha mereka masing-masing melalui laporan keuangan, misalnya kebutuhan informasi UMKM tentang omset harian, bulanan bahkan tahunan. Selain itu UMKM juga dapat mengetahui berapa laba yang dihasilkan pada setiap periode dan kemudian laba tersebut akan digunakan untuk apa saja. Pelaku UMKM pasti menginginkan usaha yang dijalankan maju dan terus berkembang. Untuk mendukung kemajuan UMKM tersebut, maka kegiatan workshop ini diselenggarakan.

Standar akuntansi merupakan suatu hal yang sulit diterima bagi orang yang belum pernah belajar akuntansi. Maka, dengan adanya SAK EMKM memberikan standar minimal bagi UMKM untuk menginformasikan kondisi usaha kepada pihak-pihak yang membutuhkan (Barusdkk, 2020). Pelaku UMKM di Banten perlu mendapatkan pengetahuan bukan hanya tentang laporan keuangan, namun juga Laporan keuangan berbasis EMKM. Pengetahuan tentang laporan keuangan berbasis SAK EMKM disampaikan dengan beberapa tahapan, yaitu pendaftaran. Pendaftaran tentunya dilakukan karena kegiatan ini dibutuhkan bagi pelaku UMKM yang benar-benar membutuhkan pengetahuan tentang laporan keuangan, dan diharapkan peserta yang telah melakukan pendaftaran hadir sehingga materi yang disiapkan akan tepat sasaran. Kemudian penyampaian materi laporan 
keuangan UMKM berbasis SAK EMKM dilakukan pada waktu yang telah ditentukan. Materi yang menjadi perhatian ini adalah menyajikan Laporan keuangan minimal yang harus diterbitkan oleh UMKM yaitu laporan laba rugi, laporan posisi keuangan, dan catatan atas laporan keuangan.
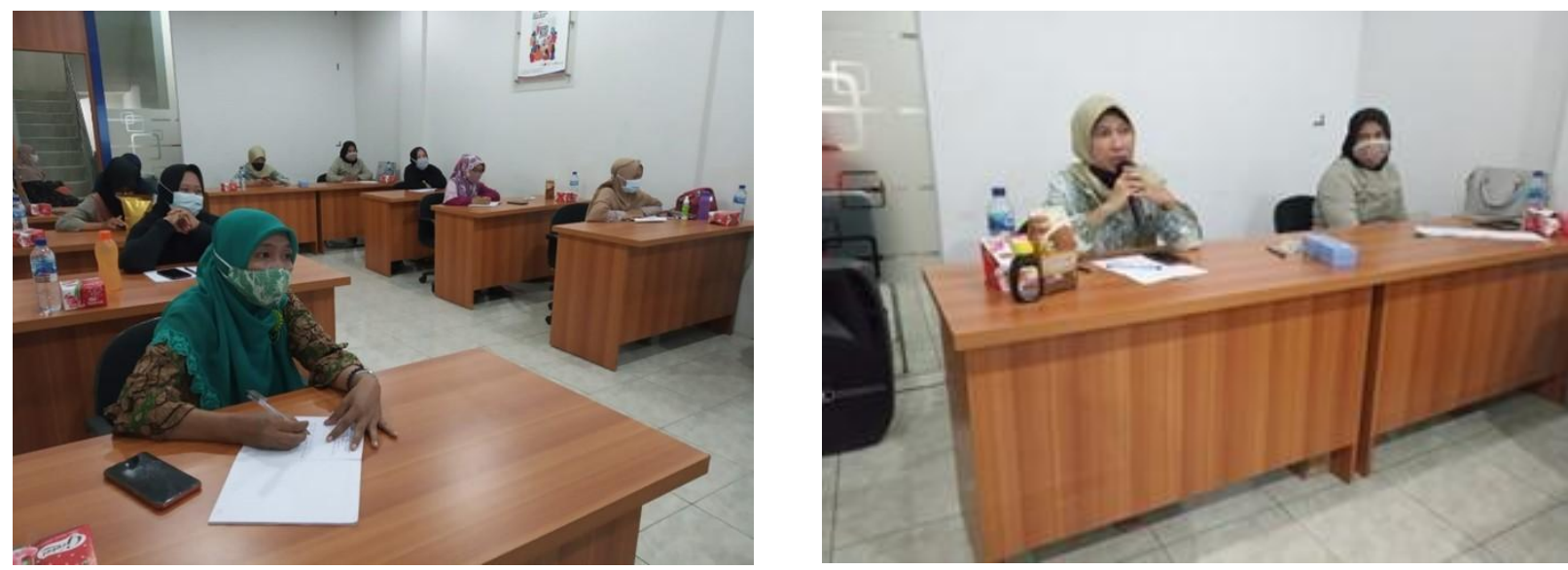

Gambar 1. Peserta Workhop Penyusunan Laporan Keuangan UMKM berbasis SAK EMKM

Laporan keuangan laba rugi memberikan manfaat bagi UMKM untuk mengetahui kinerja usaha selama satu periode (Farhan dkk, 2020). Laporan posisi keuangan merupakan laporan yang memberikan informasi tentang posisi aset, liabilitas, dan ekuitas dari suatu UMKM, selain itu ada catatan atas laporan keuangan yang merupakan informasi keuangan yang harus diungkapkan oleh UMKM secara lebih terperinci. Selain menerima materi, peserta workshop juga mendapatkan kesempatan praktik menggunakan Aplikasi Akuntansi UKM melalui smartphone mereka masingmasing. Aplikasi tersebut didownload melalui Google Playstore secara gratis. Aplikasi ini telah menggolongkan masing-masing akun sehingga pemakai mudah melakukan jurnal. Pelaku UMKM diberikan sebuah kasus usaha "Brownis". Pada kasus tersebut tersedia transaksi selama satu bulan, dari kasus tersebut dipraktikkan bersama-sama di kelas. Peserta diminta menginput setiap transaksi, setelah seluruh transaksi diinput maka dapat dilihat laporan keuangan pada akhir periode. Laporan keuangan dapat dihasilkan dengan mudah bagi pelaku UMKM (Yuniadkk, 2020). Dengan demikian, UMKM yang memiliki informasi tentang laporan keuangan dapat membuat keputusan tentang usahanya, apakah harus menambah modal, membuka cabang di tempat yang lain, atau bahkan apakah usaha tersebut harus ditutup. Begitu pentingnya laporan keuangan bagi UMKM, maka setiap UMKM harus menginformasikan kondisi usaha melalui laporan keuangan.

Pada akhir kegiatan, dilakukan evaluasi atas kegiatan Workshop Penyusunan Laporan Keuangan UMKM berbasis SAK EMKM dilaksanakan melalui aplikasi Kahoot.it. Berdasarkan hasil pada aplikasi tersebut, semua peserta menjawab pertanyaan yang disampaikan, namun masih ada beberapa peserta yang menjawab pertanyaan salah. Berdasarkan hasil evaluasi, ditentukan tiga peserta dengan nilai tertinggi untuk memperoleh hadiah dari penyelenggara. Berdasarkan hasil tersebut, dapat diketahui bahwa peserta kegiatan antusias selama mengikuti kegiatan, selain itu peserta sadar akan pentingnya laporan keuangan bagi perkembangan usaha mereka. Dengan dilaksanakannya kegiatan tersebut, pelaku UMKM dapat menerapkan ilmunya pada usaha yang dijalankan. 

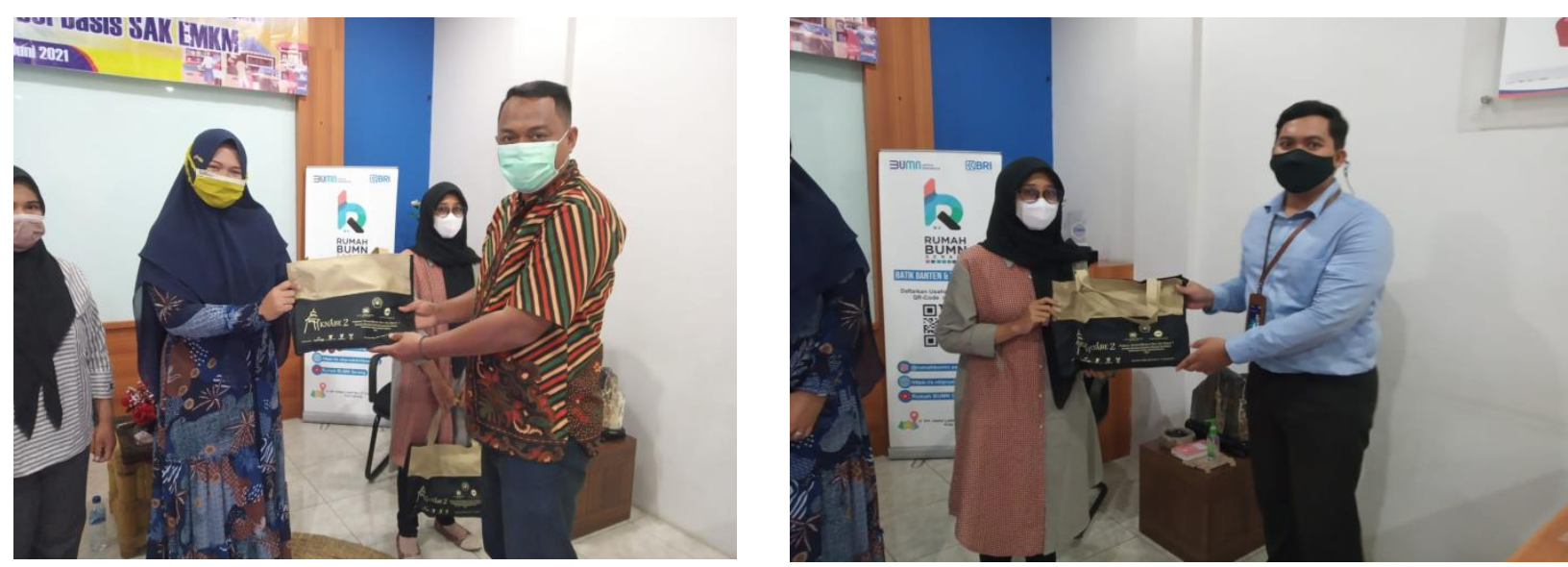

Gambar 2. Penyerahan hadiah kepada peserta

Sebagai bahan monitoring bagi penyelenggara kegiatan, pendampingan dilaksanakan setelah kegiatan workshop ini. Pendampingan dilakukan secara online melalui grup media sosial yang telah terbentuk. Pada grup tersebut peserta dapat menyampaikan kendala terkait dengan pencatatan keuangan. Setelah mengikuti serangkaian kegiatan workshop penyusunan laporan keuangan UMKM berbasis SAK EMKM, maka pelaku UMKM dapat memahami pentingnya menyajikan laporan keuangan yang baik dan benar. Mengingat pentingnya UMKM pagi penggerak perekonomian, maka UMKM di Provinsi Banten yang memiliki jumlah besar, berarti UMKM ini merupakan salah satu penggerak ekonomi di Provinsi Banten. Dengan menyediakan laporan keuangan berbasis SAK EMKM, maka UMKM di Provinsi Banten dapat bersaing dengan UMKM secara nasional, bahkan secara internasional. Dengan memiliki laporan keuangan berbasis SAK EMKM, menunjukkan bahwa UMKM di Provinsi Banten memiliki keinginan yang kuat untuk maju dan berkembang.

\section{KESIMPULAN}

Simpulan yang dapat diambil berdasarkan kegiatan Workshop Penyusunan Laporan keuangan UMKM berbasis SAK EMKM adalah pelaku UMKM perlu diberikan pengetahuan tentang pentingnya laporan keuangan sesuai dengan standar akuntansi yang berlaku. Selain pengetahuan, pelaku UMKM harus diberikan pelatihan praktis tentang penyusunan laporan keuangan supaya dapat menghasilkan laporan keuangan secara mandiri. Laporan yang dihasilkan oleh UMKM dapat digunakan sebagai salah satu bahan pengambilan keputusan bagi pelaku UMKM.

\section{UCAPAN TERIMA KASIH}

Ucapan terima kasih atas terselenggaranya kegiatan pengabdian kepada masysrakat kami sampaikan kepada pihak-pihak yang telah bekerja sama yaitu Fakultas Ekonomi dan Bisnis, Universitas Sultan Ageng Tirtayasa, Ikatan Akuntan Indonesia Wilayah Banten, Rumah Kreatif BUMN BRI Serang, peserta dan panitia.

\section{REFERENSI}

Barus, I. S. L., \& Suharman, H. (2020). Pencatatan dan Penyusunan Laporan Keuangan Berdasarkan SAK EMKM Tahun 2018 Pada UKM Sektor Perdagangan di Kabupaten Bandung. Tirtayasa Ekonomika, 15(2), 253-270.

Bidang Neraca Wilayah dan Analisis Statistik. 2016. Potensi Usaha Mikro, Kecil Provinsi Banten Sensus Ekonomi 2016. Badan Pusat Statistik Provinsi Banten.

Dinas Koperasi dan UKM. 2018. Jumlah Usaha Mikro, Kecil dan Menengah menurut Kabupaten/Kota di Provinsi Banten Tahun 2018. https://statistik.bantenprov.go.id/ ekonomi/koperasi

Farhan, M., Novriansa, A., Kalsum, U., \&Mukhtaruddin, M. (2020). Pengenalan Akuntansi bagi Usaha Mikro Kecil dan Menengah (UMKM) di Desa Kota Daro, Kabupaten Ogan llir. Sricommerce: Journal of 
Sriwijaya Community Services, 1(1), 47-54.

Febriyanto, D. P., Soegiono, L., \& Kristanto, A. B. (2019). Pemanfaatan Informasi Keuangan dan Akses Pembiayaan Bagi Usaha Mikro Kecil dan Menengah. Jurnal Ilmiah Akuntansi dan Humanika, 9(2).

Ikatan Akuntan Indonesia. 2016. Standar Akuntansi Keuangan Entitas Mikro, Kecil dan Menengah. Jakarta: Ikatan Akuntan Indonesia.

Yunia, D., Mulyasari, W., Nofianti, N., \&Astuti, K. D. (2020). Pelatihan Laporan Keuangan UMKM Menggunakan Smartphone. ARSY: Jurnal Aplikasi Riset kepada Masyarakat, 1(1), 58-64. 